\title{
Introduction - Managing Innovation: Understanding International Innovation
}

\author{
Alexander Brem, Joe Tidd and Tugrul Daim
}

\section{Phenomenon ${ }^{1}$}

Globalization is the main economic phenomenon of the last centuries. Since the late 1980s, multinational companies (MNCs) from Europe and North America are shifting their production to Asian countries, especially to China and other Asian countries. Due to the growing markets in Asia, $R \& D$ was shifted there as well to appropriately adapt new products to local needs, but at a very low level (Edler et al., 2003). However, this is changing in recent years through frugal and reverse innovation (Agarwal et al., 2017). At the same time, these countries earned a huge amount of know-how, based on these technology transfers, and unbelievable amounts of foreign currency reserves (Klossek et al., 2012).

In recent years, before the background of internationalization of these companies, the situation turned upside down (Schueler-Zhou and Schueller, 2009). Global companies invest in Asian R\&D capabilities not only to adopt products on local needs but rather to use foreign knowledge sources and scientific capabilities (Veugelers, 2005; Brem and Freitag, 2015). Because on a macroeconomic level, from 2009 to 2010, Chinese expenses for R\&D, which are already at a comparatively high level, increased by $38.5 \%$. The average of this study was about $9.3 \%$ (Jaruzelski et al., 2011). Another study by the United Nations revealed that $62 \%$ of all interviewed persons named China as their favorite new R\&D site; $41 \%$ stated the USA, 29\% India (UNCTAD, 2005).

On the microeconomic level, there is another trend of growing Research and Development (R\&D) activities in Asian countries, to develop their own innovation capabilities, which are not dependent on foreign companies anymore (Jiatao and Rajiv, 2009; Gerybadze and Reger, 1999; Kumar, 1997; Brem and Moitra, 2012). Consequently, the number of innovations originated in China is growing, especially

\footnotetext{
${ }^{1}$ Based on Brem and Moitra, 2012.
} 
by China-based MNCs (Zeschky et al., 2011), and there is a high level of support by the Chinese government (Di Minin and Zhang, 2010). However, these companies must further develop their innovation capabilities to enhance technical innovation. For this, the focus must change from process to product innovation and from imitation to indigenous innovation ( $\mathrm{Li}$ and Kozhikode, 2009).

Particularly, emerging Asian companies invest their money into strategic knowhow all over the world, e.g., not only in technical rights like patents or licenses but in joint ventures and acquisitions as well (Schueler-Zhou and Schueller, 2009). In 2006, 11 billion US dollars were invested from European and American companies in Indian companies. On the contrary, Indian companies spent about 23 billion US dollars for 168 acquisitions in other countries (Rybak, 2007). In Germany, about 1,300 active Chinese companies spent about 1.7 trillion US dollars in German companies; in 2011 alone, these firms spent about 230 billion US dollars (Brüggmann, 2011). Until 2020, more than 2 trillion euros are expected to be invested in Germany.

These companies are using a variety of establishment modes to gain access to new markets.

Some prominent examples from such acquisitions by Chinese companies in 2011 are

- Lenovo bought Medion (Germany)

- CITIC bought KSM Castings (Germany)

- Wolong bought ATB Antriebstechnik (Austria)

- Youngman und Pang Da bought Saab (Sweden)

These examples show how far the internationalization of innovation already went within a comparably short timeframe. Hence, it is interesting to analyze in more detail how we can foster a common understanding of these developments. For this, current phenomena like lean and global innovation are also discussed.

\section{Understanding International Innovation}

International innovation mainly happens within the context of MNCs. These firms usually have enough resources to foster innovation at different locations all over the world, with distributed competences and organizational units. As Liu and Shi (2017) outline, factors like the development of Information and Communication Technologies (ICT), competitive pressure, brand awareness and technological capabilities determine the choice of how the company develops new products and allocate these resources. This is usually achieved through the application of New Product Development (NPD) approaches, which can be multi-local as well as 
adaptation- or platform-based. To achieve such a competitiveness at an international scale, certain innovation capabilities are needed. Based on further strategic, organizational and operational aspects, Brem and Freitag (2016) argue that some of the general management approaches can be applied universally, while others differ a lot in cultural setups. In their case of India, different expectations must be considered in order to be successful, e.g., reward systems are quite different, but also the average age of NPD teams. Only an appropriate awareness of these factors will lead to the expected success.

Sato (2014) uses the example of telecommunication operators to explain when platform-based innovation approaches work best. Zhou et al. (2016) argue in this context that innovation capabilities, organization structures and the interaction between the subsidiary and the headquarter determine the overall innovation success. For this, he found that the reusability of components and its sub-systems as well as the openness of platforms to externals drive innovation success in this industry in an international context. This phenomenon has become even more prominent in times of the sharing economy and their related platform strategies (Richter et al., 2017). However, Sato (2014) also highlights that the low level of internationalization (in the case of telecom operators) might also harm the dynamics of such platform-based strategies. Such internationalization efforts can also be measured with export intensity. This path was chosen by Podmetina et al. (2009) who found that there is a significant impact of innovation activities, level of competition and NPD activities on this intensity, based on their Russian sample. However, there is also always an inherent risk of being imitated, as the success is then also visible on a global scale. Based on the results of Foege et al. (2017), there is an indication that the probability of being imitated increases with the partnership variety. In such a situation, companies need to carefully select whom to work with and how the relationship can be secured.

\section{Lean and Global Innovation}

Following research avenues on the internationalization of innovation in recent years inevitably ended up with reading about lean and global innovation setups. One of these approaches ended in the definition of Lean Global Start-Ups (LGS) by Tanev et al. (2015), which faces the specific combination of business development, new product development and early internationalization. They further distinguish between lean-to-global and lean-and-global firms, whereby both have high levels of complexity, uncertainty and risk on a global scale. Hence, knowledge sharing and Intellectual Property (IP) protection have an even higher importance, but also an even higher complexity, as they also happen on a global level. Buse et al. (2010) already identified such barriers to innovation in their study on SMEs in Western countries. 
As a result, they recommend that firms should decide on a specific form of internationalization: captive offshoring, offshore cooperation or offshore outsourcing. As a consequence of such internationalization efforts, spin-offs may occur. Early internationalization of such spin-offs using the spin-along idea (Rohrbeck et al., 2007) can avoid or even reduce the main problems they are facing (Mahdjour and Fischer, 2014). A main dimension for such "born global" firms is the ideal business model design, which they have in the best case from the start of their firm. If this setup is strategically chosen, such a business model design can also have a positive impact on the international firm performance (Kraus et al., 2016).

These results show the high dynamics of research on the internationalization of firms, which continues till today. With this overview, we would like to stimulate further reading in this edited book which contains main research milestones from the International Journal of Innovation Management as well as from the International Journal of Technology and Innovation Management on the internationalization of innovation. Finally, we also hope to encourage further research on this interesting phenomenon.

\section{Book Structure}

Table 1 below summarizes what to expect in each part and chapter. The expectations are separated for a practitioner versus a researcher or a student. The readers can review this table to identify the chapters they should focus on.

Table 1. Overview of results for practitioners and researchers/students

\begin{tabular}{|c|c|c|c|}
\hline Parts & Chapters & Practitioner focus & Researcher focus/Student focus \\
\hline \multirow[t]{4}{*}{$\begin{array}{l}\text { 1: Understanding } \\
\text { International } \\
\text { Innovation }\end{array}$} & 1 & $\begin{array}{l}\text { A review of four cases from } \\
\text { multinational corporations } \\
\text { analyzing new product } \\
\text { development. }\end{array}$ & $\begin{array}{l}\text { Case analysis identified several topics } \\
\text { that can be developed into } \\
\text { propositions to test with a field } \\
\text { study. }\end{array}$ \\
\hline & 2 & $\begin{array}{l}\text { A review of four international } \\
\text { cases from the } R \& D \text { world. }\end{array}$ & $\begin{array}{l}\text { Case analysis identified several topics } \\
\text { that can be developed into } \\
\text { propositions to test with a field } \\
\text { study. }\end{array}$ \\
\hline & 3 & $\begin{array}{l}\text { Review of the impact of } \\
\text { platform-based strategy in } \\
\text { the telecommunication } \\
\text { industry. }\end{array}$ & $\begin{array}{l}\text { A comprehensive case study } \\
\text { analysis including a series of } \\
\text { interviews. The results can be } \\
\text { used to develop propositions to } \\
\text { test with a larger sample. }\end{array}$ \\
\hline & 4 & $\begin{array}{l}\text { A review of the innovation } \\
\text { activities of foreign } \\
\text { subsidiaries in China. }\end{array}$ & $\begin{array}{l}\text { Data from a set of interviews provide } \\
\text { a platform for a future research } \\
\text { involving a larger sample and a } \\
\text { survey. }\end{array}$ \\
\hline
\end{tabular}


Table 1. (Continued)

\begin{tabular}{|c|c|c|c|}
\hline Parts & Chapters & Practitioner focus & Researcher focus/Student focus \\
\hline \multirow{6}{*}{$\begin{array}{l}\text { 2: Lean and Global } \\
\text { Innovation }\end{array}$} & 5 & $\begin{array}{l}\text { A review of the innovation } \\
\text { activities in Russia. }\end{array}$ & $\begin{array}{l}\text { A set of validated and tested } \\
\text { hypotheses that can be tested in } \\
\text { other settings. }\end{array}$ \\
\hline & 6 & $\begin{array}{l}\text { Review of imitation threats } \\
\text { in collaborative } \\
\text { innovation. }\end{array}$ & $\begin{array}{l}\text { A set of validated and tested } \\
\text { hypotheses that can be tested in } \\
\text { other settings as well as a list of } \\
\text { additional aspects that can be } \\
\text { studied within the same setting. }\end{array}$ \\
\hline & 7 & $\begin{array}{l}\text { A review of strategies for } \\
\text { technology start-ups. }\end{array}$ & $\begin{array}{l}\text { Case study results provide a future } \\
\text { research opportunity to test } \\
\text { propositions out of this study. }\end{array}$ \\
\hline & 8 & $\begin{array}{l}\text { A review of innovation } \\
\text { barriers in Germany. }\end{array}$ & $\begin{array}{l}\text { A set of preliminary areas for future } \\
\text { research on innovation success } \\
\text { factors. }\end{array}$ \\
\hline & 9 & $\begin{array}{l}\text { A case of corporate } \\
\text { entrepreneurship. }\end{array}$ & $\begin{array}{l}\text { A case study which can be used to } \\
\text { develop propositions for a future } \\
\text { expanded study. }\end{array}$ \\
\hline & 10 & $\begin{array}{l}\text { Review of business models } \\
\text { and their impact on } \\
\text { international } \\
\text { success. }\end{array}$ & $\begin{array}{l}\text { A set of validated and tested } \\
\text { hypotheses that can be tested in } \\
\text { other settings as well as a list of } \\
\text { additional aspects that can be } \\
\text { studied within the same setting. }\end{array}$ \\
\hline
\end{tabular}

\section{References}

Agarwal, N, M Grottke, S Mishra and A Brem (2017). A systematic literature review of constraint-based innovations: State of the art and future perspectives. IEEE Transactions on Engineering Management, 64(1), 3-15.

Ale Ebrahim, N, S Ahmed, Z Taha, M Personal, R Archive, A Ebrahim and K Lumpur (2010). SMEs; Virtual research and development (R\&D) teams and new product development: A literature review. International Journal of the Physical Sciences, 5(7), 916-930.

Brem, A and F Freitag (2015). Internationalisation of new product development and research \& development: Results from a multiple case study on companies with innovation processes in Germany and India. International Journal of Innovation Management, 19(1). doi: 10.1142/S1363919615500103.

Brem, A and D Moitra (2012). Learning from failure: Case insights into a UK-India technology transfer project. In: Technology Transfer in a Global Economy, pp. 253-275. Springer, US.

Brüggmann, M (2011, Oktober). China und Katar auf Einkaufstour. In: Handelsblatt, 25, Nr. 206, S. 15. 
Buse, S, R Tiwari and C Herstatt (2010). Global innovation: An answer to mitigate barriers to innovation in small and medium-sized enterprises? International Journal of Innovation and Technology Management, 7(3), 215-227. doi: 10.1142/S0219877010001970.

Di Minin, A and J Zhang (2010). An exploratory study on international R\&D strategies of Chinese companies in Europe. Review of Policy Research, 27(4), 433-455.

Economist (2010). First Break all the Rules. 395(8678), pp. 6-8.

Edler, J, R Döhrn and M Rothgang (2003). Internationalisierung industrieller Forschung und grenzüberschreitendes Wissensmanagement. Eine empirische Analyse aus der Perspektive des Standortes Deutschland, Essen - Karlsruhe.

Foege, JN, EP Piening and T Salge (2016). Don't get caught on the wrong foot: A resource-based perspective on imitation threats in innovation partnerships. International Journal of Innovation Management. doi: 10.1142/s1363919617500232.

Gerybadze, A and G Reger (1999). Globalization of R\&D: Recent changes in the management of innovation in transnational corporations. Research Policy, 28(2-3), 251-274.

Jaruzelski, B, J Loehr and R Holman (2011, Winter). The global innovation 1000 - Why culture is key. Strategy and Business, Issue 65.

Jiatao, L and KK Rajiv (2009). Developing new innovation models: Shifts in the innovation landscapes in emerging economies and implications for global R\&D management. Journal of International Management, 15, 328-339.

Klossek, A, BM Linke and M Nippa (2012). Chinese enterprises in Germany: Establishment modes and strategies to mitigate the liability of foreignness. Journal of World Business, 47(1), 35-44.

Kraus, S, A Brem, M Schuessler, F Schuessler and T Niemand (2016). Innovative born globals: Investigating the influence of their business models on international performance. International Journal of Innovation Management. doi: 10.1142/ S1363919617500050.

Kumar, N (1998). Technology generation and technology transfers in the world economy: Recent trends and implications for developing countries. Science, Technology and Society, 3(2), 265-306.

Li, J and RK Kozhikode (2009). Developing new innovation models: Shifts in the innovation landscapes in emerging economies and implications for global R\&D management. Journal of International Management, 15(3), 328-339.

Liu, Y and Y Shi (2017). Understanding international product strategy in multinational corporations through new product development approaches and evolution. International Journal of Innovation Management, 1750057.

Mahdjour, S and S Fischer (2014). International corporate entrepreneurship with born global spin-along ventures - A cross-case analysis of telekom innovation laboratories' venture portfolio. International Journal of Innovation Management, 18(3). doi: 10.1142/S1363919614400076.

Podmetina, D, M Smirnova, J Väätänen and M Torkkeli (2009). Innovativeness and international operations: Case of Russian R\&D companies. International Journal of Innovation Management, 13(2), 295-317. doi: 10.1142/S1363919609002303. 
Rohrbeck, R, M Dohler and HM Arnold (2007). Combining spin-out and spin-in activities The spin-along approach. Paper presented at ISPIM 2007 Conference: Innovation for Growth: The Challenges for East \& West, pp. 1-12, June 17. Warsaw, Poland.

Richter, C, S Kraus, A Brem, S Durst and C Giselbrecht (2017). Digital entrepreneurship: Innovative business models for the sharing economy. Creativity and Innovation Management, 26(3), 300-310.

Rybak, A (2007). Available at http://www.ftd.de/unternehmen/industrie/:agenda-indischewelteroberer/182300.html\#z.

Sato, CEY (2014). Platform leadership of incumbent telecommunications operators: The case of BT 21ST century network (BT21CN). International Journal of Innovation Management, 18(2), doi: 10.1142/S1363919614500157.

Schueler-Zhou, Y and M Schueller (2009). The internationalization of Chinese companies - What do official statistics tell us about Chinese outward foreign direct investment?Chinese Management Studies, 3(1), 25-42.

Tanev, S, ES Rasmussen, E Zijdemans, R Lemminger and LL Svendsen (2015). Lean and global technology start-UPS: Linking the two research streams. International Journal of Innovation Management, 19(3). doi: 10.1142/S1363919615400083.

UNCTAD (2005). WORLD INVESTMENT REPORT 2005 WIR 2005 UNCTAD/WIR/ 2005. Available at: http://unctad.org/en/Docs/wir2005_en.pdf [Accessed May 29, 2017].

Veugelers, R (2005). Internationalisation of $R \& D$ in the $U K-A$ Review of the Evidence. Leuven - Cambridge.

Zeschky, M, B Widenmayer and O Gassmann (2011). Frugal Innovation in emerging markets: The case of mettle. Research-Technology Management, 54(4), 38-45.

Zhou, W, VK Velamuri and T Dauth (2016). Changing innovation roles of foreign subsidiaries from the manufacturing industry in China. International Journal of Innovation Management. doi: 10.1142/S1363919617500086. 